\title{
Urgences
}

\section{Cinq amances en mai}

\section{Réjean Dubé}

Numéro 2, 3e trimestre 1981

URI : https://id.erudit.org/iderudit/025020ar

DOI : https://doi.org/10.7202/025020ar

Aller au sommaire du numéro

Éditeur(s)

Urgences

ISSN

0226-9554 (imprimé)

1927-3924 (numérique)

Découvrir la revue

Citer ce document

Dubé, R. (1981). Cinq amances en mai. Urgences, (2), 5-8.

https://doi.org/10.7202/025020ar

Ce document est protégé par la loi sur le droit d'auteur. L’utilisation des services d'Érudit (y compris la reproduction) est assujettie à sa politique d'utilisation que vous pouvez consulter en ligne.

https://apropos.erudit.org/fr/usagers/politique-dutilisation/
Cet article est diffusé et préservé par Érudit.

Érudit est un consortium interuniversitaire sans but lucratif composé de l’Université de Montréal, l'Université Laval et l'Université du Québec à Montréal. Il a pour mission la promotion et la valorisation de la recherche. https://www.erudit.org/fr/ 
RÉJEAN DUBÉ

Cinq amances en mai 
1. au delà des césures par delà les noeuds trop attendus persiste un filet d'eau lune longtemps

pour encore 
2. entre vos gambades douces-pleures oyez-vous ce chuintement d'encre tendre

3. entre deux murs un peu d'eau puisée au fond de l'air attend

d'autres sons d'aube 
4. un nuage citron d'amande nu l'herbe sous les pieds entre les doigts touchent

5. saurons-nous étreindre parallèles douces mus que par l'ivresse de l'oeil et des chairs si 